\title{
Menabur Benih Politik Berkeadaban
}

\author{
Saortua Marbun ${ }^{1}$ \\ ${ }^{1}$ Sekolah Tinggi Ilmu Ekonomi Triatma Mulya
}

October 9, 2018

\section{Menabur Benih Politik Berkeadaban}

\section{Saortua Marbun(Marbun, 2018a)}

Sekolah Tinggi Ilmu Ekonomi Triatma Mulya

saortuam@gmail.com | http://orcid.org/0000-0003-1521-7694

DOI: $10.22541 / \mathrm{au} .151623662 .20184822$

(C)2018 Saortua Marbun

"Tampaknya Bawaslu dan Satgas Anti Money Politic, anti SARA, anti hoaks - kali ini tidak main-main. Jangan sampai dirimu tertangkap tangan kawan. Jika tidak takut dilihat oleh TUHAN, setidaknya takutlah pada kamera $C C T V$, hidden cameras, "mata-mata", kamera media massa."Begitulah isi salah satu cuitan yang diposting di media sosial.(Marbun, 2018b)

Menurut Amartya Sen (2009) di dalam Rido (2017) , hakikat demokrasi adalah terdorongnya fungsi pembangun dalam pembentukan nilai-nilai dan pentingnya hakikat kehidupan manusia (kesejahteraan). Akan tetapi realitanya belum demikian. Wattimena (2018), menulis bahwa "politik telah tercabut" dari keutamaan, tercabut dari spiritualitas, tercabut dari ilmu pengetahuan dan tercabut dari budaya. Oleh sebab itu Negara harus menunjukkan "taringnya" - agar hajatan politik - tahun ini dan seterusnya - kembali ke jati diri politik luhur, hakikat demokrasi. Politik tercabut dari keutamaan dan filsafat yang mendasarinya, sehingga ia berubah menjadi transaksi kekuasaan yang mengorbankan kepentingan rakyat luas. Politik yang sejatinya sebuah profesi luhur untuk mewujudkan konsensus demi kebaikan bersama melalui kebijakan cerdas dan keteladanan. Keluhuran profesi ini bagai "lenyap" ditelan oleh "syahwat" kekuasaan. Politik bermetamorfosa menjadi musuh-musuh kebaikan. Sikap dan perilaku berpolitik masa kini telah memisahkan diri dari narasi kesantunan. Internalisasi nilai dan kultur demokrasi berkeadaban pada level massa - terpinggirkan.

Politik sudah tercabut dari ilmu pengetahuan. Beragam kebijakan politik diproduksi tanpa dasar rasionalitas, tanpa dukungan penelitian ilmiah yang bermutu. Berulangkali publik dibuat tidak berdaya oleh kebijakan politik yang dibuat atas dasar persekongkolan dengan pemilik modal yang korup, ujungnya merugikan kepentingan publik. Beragam kebijakan yang ada justru tidak masuk akal sehat, terkadang memperburuk persoalan yang sudah ada. Politik sudah tercabut dari spiritualitas atau cara hidup yang mengedepankan aspek-aspek kemanusiaan universal di dalam segala keputusan dan perilaku. Politik masa kini telah menghimpit spiritualitas menjadi sebatas agama yang dijadikan kendaraan dan menjadi topeng untuk menutupi aroma amis dari kebusukan. Sadar atau tidak, kampanye politik yang menunggangi agama menjadi salah satu indikasi bahwa aktor dan dalang di balik layar itu korup. 
Politik sudah tercabut dari budaya, ia menjadi korban dari nilai-nilai yang diimport dari nilai-nilai Barat dan Timur Tengah. Alhasil, nilai-nilai luhur budaya setempat terkikis, lenyap. Politik yang tercabut dari budaya justru menciptakan keterasingan dan melahirkan kemiskinan dan kebodohan yang semakin parah di tengah masyarakat. Demokrasi masa kini telah menciptakan "permusuhan" antar pendukung - para pihak memandang yang lain sebagai musuh politik, mereka saling berhadap-hadapan pada pemilihan kepala desa, bupati, walikota, gubernur, legislatif hingga pemilihan presiden. Ketegangan elektoral tahun 2013 yang lalu rasanya masih segar, kini 2018 publik berharap demokrasi berlangsung dalam suasana teduh.

Rasanya tepat membaca kembali tulisan Thohari (2014), "Pada masa lalu perebutan kekuasaan dan takhta dilakukan dengan peperangan yang sarat dengan kekerasan dan pertumpahan darah. Politik demokrasi memberikan mekanisme "perebutan takhtaßecara adil, sehat, dan berkeadaban melalui pemilihan umum. Maka, sangat ironis jika pemilihan umum yang mestinya berkeadaban itu kembali diperlakukan menjadi laksana peperangan perebutan takhta yang keras, kasar, dan brutal seperti masa pramodern dulu.-Oleh sebab itu, keseriusan penyelenggara bersama seluruh pemangku kepentingan tentu sangat diperlukan dalam upaya menyemai benih politik yang sehat seraya memutus akar-akar politik yang bermasalah. Masa depan, keutuhan dan kesejahteraan bangsa menjadi taruhannya - bila upaya ini gagal maka politik akan menjadi mesin penghancur yang membawa petaka kemiskinan, penderitaan, kehancuran moral.

Firman Allah berkata, "Bangsa yang tidak mendapat bimbingan dari TUHAN menjadi bangsa yang penuh kekacauan. Berbahagialah orang yang taat kepada hukum TUHAN." (Amsal 29:18, BIS) (sab). 


\section{References}

Amsal 29:18 (Versi Paralel) - Tampilan Ayat - Alkitab SABDA. http://alkitab.sabda.org/verse.php?book=amsal\&chapter=29\&verse=18. URL http://alkitab . sabda.org/verse.php?book=amsal\&chapter=29\&verse=18. Accessed on Thu, January 18, 2018.

Saortua Marbun. Menabur Benih Politik Berkeadaban - Mimbar Protestan. Surat Kabar Pos Bali, Jan 18 (6), 2018a. URL https://www.posbali.id/.

Saortua Marbun. Tampaknya Bawaslu dan Satgas Anti Money Politic ... Facebook.com, Jan 17, 2018b. URL https://www.facebook.com/satyamarbun/.

Ali Rido. Mencegah Kebablasan Demokrasi. Kompas, Maret 25 (6), 2017. URL http://doa-bagirajatega . blogspot.com/2017/03/mencegah-kebablasan-demokrasi-ali-rido.html. Accessed on Thu, January 18,2018

Hajriyanto Y Thohari. Pilpres 2014: "Perang Semua Melawan Semua". Kompas, Jun 24, 2014. URL http:// doa-bagirajatega.blogspot. com/2014/06/pilpres-2014-perang-semua-melawan-semua.html. Accessed on Thu, January 18, 2018.

Reza A.A Wattimena. Anti-Politik: Politik yang Tercabut. Rumahfilsafat.com, Jan 16, 2018. URL https:// rumahfilsafat.com/2018/01/16/anti-politik-politik-yang-tercabut/. Accessed on Thu, January $18,2018$. 